\title{
Floristic and vegetation successional processes within landslides in a Mediterranean environment
}

\author{
Carlos Neto, Patrícia Cardigos, Sérgio Cruz Oliveira *, José Luís Zêzere \\ Centre for Geographical Studies, IGOT (Institute of Geography and Spatial Planning), Universidade de Lisboa, Edifício IGOT, Rua Branca Edmée Marques, 1600-276 Lisboa, Portugal
}

\section{H I G H L I G H T S}

- A method to understand successional processes in disturbed landslide areas is presented.

- A floristic and vegetation analysis is performed considering different landslide sectors.

- A gradient in the seral vegetation stage is observed from landslide scarp to foot.

- Landslide disturbed areas can be biodiversity reservoirs.

\section{G R A P H I C A L A B S T R A C T}

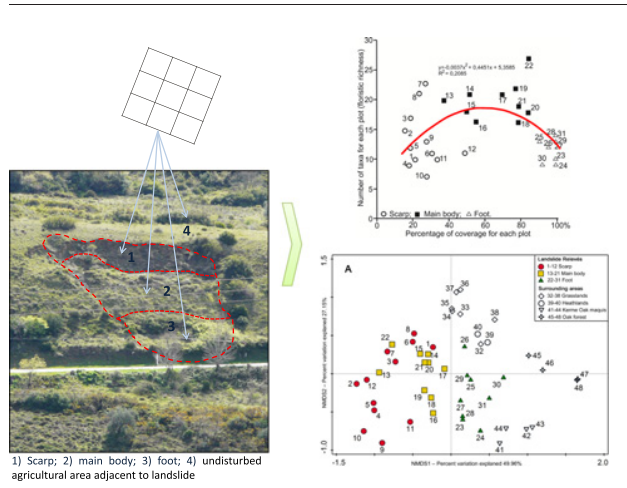

\section{A B S T R A C T}

Floristic and vegetation analysis in seven Mediterranean landslides led to the understanding of the successional processes occurring in different landslide disturbed sectors. Our study showed that in landslides that occurred between 1996 and 2010 there is a clear differentiation between the three main landslide sectors (scarp, main body and foot) concerning floristic composition, vegetation structure, floristic richness, successional processes and plant functional type. Additional differences were found between landslide areas and undisturbed agricultural areas adjacent to landslides. In this study 48 floristic relevés were made using a stratified random sampling design. The main landslide body exhibits the highest floristic richness whereas the landslide scarp has the lowest coverage rate and the highest presence of characteristic species from ruderal and strongly perturbed habitats. Finally, the landslide foot shows a late stage in the succession (maquis or pre-forest stage) with a high dominance of vines. We further discuss the importance of landslides as reservoirs of biodiversity especially for Mediterranean orchids.

C 2016 Elsevier B.V. All rights reserved.

\section{Introduction}

Disturbances caused by natural disasters such as earthquakes, typhoons, landslides, floods and forest fires, among others, change the biological organization of ecosystems (del Moral and Walker, 2007).

\footnotetext{
* Corresponding author.

E-mail address: cruzdeoliveira@campus.ul.pt (S.C. Oliveira).
}

These events often lead to primary or secondary succession, depending on whether the disturbance involves species changes on substrates with little or no biological legacy (primary succession) or the succession begins with some biological legacy (secondary succession) (Franklin et al., 1985; Walker and del Moral, 2003; Geertsema and Pojar, 2007; Walker and Shiels, 2013). The study of environmental disturbances has a long research tradition focusing on different impacts, restoration and succession process (White and Jentsch, 2001; Restrepo et al., 2009). Landslides 
are major phenomena responsible for natural disturbance on ecosystems removing organic matter and topsoil, exposing bare rock and shallow subsoil and generating extreme environmental gradients (Myster and Femández, 1995; Myster, 1997; Pearson et al., 2013). These natural disturbances provide new substrates for plants and community development and alter the landscape (Elias and Dias, 2004, 2009). The mobilization of soil mass (engineering perspective) takes place when a landslide occurs allowing the study of the successional processes, as well as the analysis of the competition processes among colonizing plants.

The principle of ecological succession on landslides is well established with the nature and rate of succession being determined by changes in soil type, available nutrients, light, wind and hydrology (Walker et al., 1996; Myster and Walker, 1997; Stokes et al., 2007; Shiels and Walker, 2013). However, the ecological characteristics of habitats created by the landslide are not homogeneous and a longitudinal gradient (from upper to lower landslide zone) of the chemical and physical properties may exert a big influence on the spatial distribution of flora and vegetation and on the successional process (Lundgren, 1978; Adams and Sidle, 1987; Guariguata, 1990; Reddy and Singh, 1993; Francescato et al., 2001; Shiels et al., 2008). According to Guariguata (1990) the lower zone of the landslide (the landslide foot) has higher concentration of carbon and total organic nitrogen exchangeable cations than the upper landslide rupture zone. On the other hand, the changes in soil structure and texture induced by the soil mass mobilization leads to a spatial differentiation of water-holding capacity and root penetrability among the different landslide zones. The spatial mosaic of habitats provided by the soil mass mobilization leads to different plant strategies and functional types of colonization of the main landslide sectors.

Worldwide studies on how landslides alter the structure of populations, communities and ecosystems relate to the soil characteristics and floristic and structural comparison between the landslide and the undisturbed adjacent area (Lundgren, 1978; Zarin and Johnson, 1995a; Restrepo and Alvarez, 2006; Elias and Dias, 2009). Some studies, however, explore plant succession on landslides (Flaccus, 1959; Mark et al., 1989; Dalling, 1994; Zarin and Johnson, 1995b; Francescato and Scotton, 1999; Gers et al., 2001; Elias and Dias, 2009; Walker et al., 2009; Walker and del Moral, 2009; Walker et al., 2010a, 2010b; Walker et al., 2013). However, only a few studies focus on the differentiation of flora and vegetation within different landslide sectors, especially the scarp, the main body and the foot (Sakai and Ohsawa, 1993; Velázquez and Gómez-Sal, 2008, 2009; Velázquez et al., 2014).

Our study aims: (i) to identify the flora and vegetation differences between the three main sectors of a landslide (scarp, main body, foot) as a consequence of the different habitat characteristics created by the moving soil mass (longitudinal gradients); and (ii) to find out whether the differences in floristic composition and vegetation structure are reflected in the succession process; (iii) to find out if the three landslide sectors of landslides of similar ages are now in the same seral stage or if the succession process has produced different seral stages along the longitudinal gradients and compare these seral stages with those of the undisturbed areas adjacent to the landslides but submitted to agricultural processes that have not taken place in the landslide area; and concerning the floristic composition (iv) to find out the contribution of landslides towards the formation of nodes or hotspots of non-forested or non-shrubby habitat and biota (Geertsema and Pojar, 2007) that in the Mediterranean region are fundamental to the preservation of many protected plants, mainly of the Orchidaceae family, some of which are rare.

\section{Study area}

As test site we selected a set of seven landslides (Fig.1; Table 1) that occurred within a $4.5 \mathrm{~km}^{2}$ study area north of Lisbon, specifically, along the small catchment of the Pequeno River. The study area is characterized by the existence of a monocline structure with lithological layers dipping south from $5^{\circ}$ to $25^{\circ}$. The dominant lithological outcrops are: carbonated rocks of Jurassic age, volcanic dykes and alluvial deposits filling the valley bottom. The carbonated rocks are essentially associated to a lithological complex of limestones and marls. The northern section of the study area comprises two minor outcrops of pelites, sandstones, marls and limestones. The elevation ranges from $120 \mathrm{~m}$ in the southern central part of the study area along the channel of the Pequeno River to $310 \mathrm{~m}$ in the Alrota hill. The major slopes are part of the Pequeno River valley that flows from the north to the south following the dip of the geological layers.

The differential erosion during the Quaternary generated a hilly landscape that includes structural landforms (cuestas) and large erosional depressions such as the Arruda dos Vinhos basin located $10 \mathrm{~km}$ northwards of the study area. Additional elements on the geomorphology of the area north of Lisbon can be found, for example, in Ferreira and Zêzere (1997), Zêzere et al. (1999) or Zêzere et al. (2008).

The natural vegetation in the studied territory is dominated by Portuguese oak forests and the respective substitution communities as presented in Table A1. According to the national cartography of land use cover (COS-Soil Occupation Map form 1990 and 2007) the majority of the studied landslide test sites underwent substantial changes between the early 1990's and 2007, in particular reverting from agricultural to shrub areas (Table 1) due mainly to the progressive abandonment of agricultural activities.

The climatic characteristics of the study area are defined based on the climate profile obtained from the São Julião do Tojal meteorological station, located $10 \mathrm{~km}$ south of the study area and with a Mean Annual Precipitation - MAP of $730 \mathrm{~mm}$ (Zêzere and Trigo, 2011). The contrast between the wet period (October to May) and the drier period (June to September) is clear. Shallow landslides are typically triggered by intense rainfall accumulating within a 1 to 15-day period (Zêzere et al., 2005; Zêzere et al., 2015).

\subsection{Landslide data}

Data on landslides in the study area (Fig. 1) was acquired through detailed field geomorphological mapping. All the landslides occurred within the lithological unit composed by limestones and marls dated from the lower Tithonian. Table 1 summarizes the main characteristics and morphometric properties of the seven landslides that make up the test site. With the exception of landslide \#5, all studied landslides occurred within a similar time span (1996-2010), 6 to 20 years ago. Their position on the slopes is mainly associated with elevations ranging from 158 to $253 \mathrm{~m}$ and on moderate to steep slopes $\left(22^{\circ}\right.$ to $\left.36^{\circ}\right)$. This slope variation is related to the lithological variations along the lower Tithonian lithological formation (Fig. 1) where steeper slopes are typically associated to limestones layers or interbedded limestones and marls, which originate rock halls on the slope top or along the middle slope. The landslide areas are mainly oriented to the E, NW and W. With respect to the landslide magnitude, defined by landslide area, length and width, landslides are essentially small (maximum landslide area $\pm 3300 \mathrm{~m}^{2}$ ).

\section{Methods}

In order to answer the initial question about the floristic and physiognomic-structural differentiation between the vegetation on the different landslide sectors (landslide scarp, main body, foot and undisturbed area adjacent to landslide) seven landslides and seven landslides strata were selected. Thus we ensure that the results are not influenced by a substantial age difference between landslides or by a considerable human influence (agricultural activities or fire impact).

In order to understand the floristic differentiation between the different landslide sectors seven landslide strata were defined (Fig. 2): 


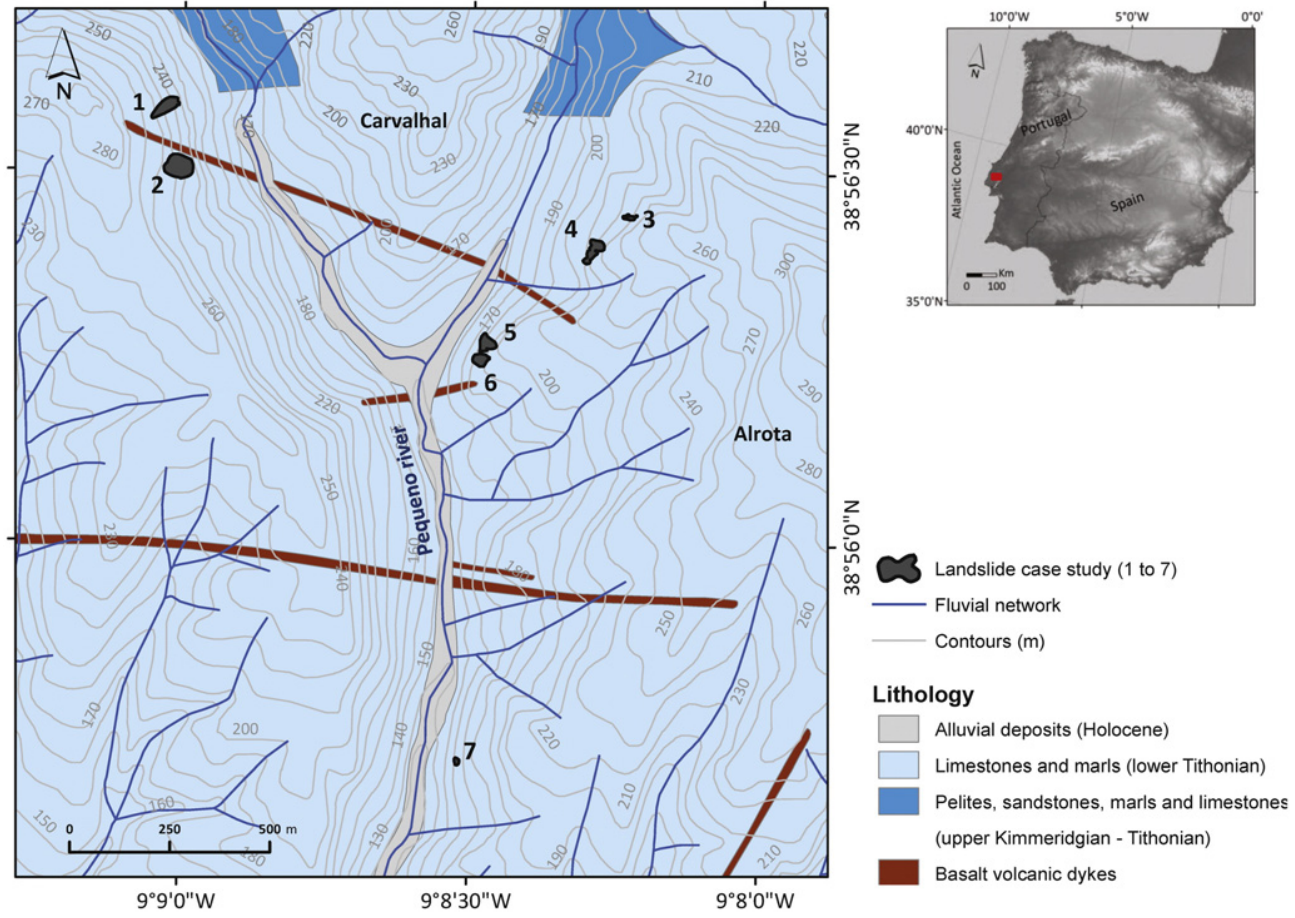

Fig. 1. Location of study area and landslides case study.

1 - Scarp; 2 - Main body; 3 - Foot; 4 - Undisturbed area adjacent to landslide, and for the latter 4 sub-divisions were considered: $4 \mathrm{a}$ - Oak forest; 4b - Maquis of Quercus coccifera in mosaic with Brachypodium phoenicoides grasslands; $4 \mathrm{c}$ - Heathland in mosaic with Brachypodium phoenicoides grasslands; 4d - Brachyopodium phoenicoides grasslands. Forty-eight relevés were considered in this study using a stratified random sampling design. The random distribution and spatial position of relevés within landslide sectors and undisturbed area adjacent to landslides was further obtained randomly using the ArcGIS Geostatistical Analyst tool. For that purpose, a grid layer $(5 \times 5 \mathrm{~m})$ was created and superimposed onto each landslide and to $200 \mathrm{~m}$ outside the landslide delineation. In this study, the $200 \mathrm{~m}$ buffer areas outside the landslides delineation were considered as the undisturbed area adjacent to landslides. Finally, a numeric ID was assigned to each square grid centroid and a random selection was performed. In this process we try to guarantee, in an iterative way, that approximately $60 \%$ of the relevés are uniformly distributed within the different landslide sectors (approximately 10 relevés for each landslide sector: landslide scarp, main body and foot) and the remaining $40 \%$ of relevés distributed along the undisturbed area adjacent to landslides (landslide strata defined previously from 4 a to $4 d$ ). The final distribution of relevés by landslide strata was defined according to the distribution shown in Table 2.

In the relevés we used a quadrat size of $1 \mathrm{~m}^{2}$ for annual and perennial herbaceous vegetation (grasslands), $5 \mathrm{~m}^{2}$ for low shrubby vegetation (garrigues), $25 \mathrm{~m}^{2}$ for medium to high shrubby vegetation (maquis) and $100 \mathrm{~m}^{2}$ for arboreal vegetation (marcescent oak forest of Quercus faginea ssp. broteroi, leaves wither in autumn but remain dry on the branches until spring). The quadrat area for each type of vegetation was determined by the minimal area quadrat method (species area curve/asymptotic curve) as described by Mueller-Dombois and Ellenberg (1974), Westhoff and van der Maarel (1978), and are in agreement with standard dimensions for different types of vegetation proposed by Chytrý and Otýpková (2003) and van der Maarel (2005).

Square size was kept constant within the same type of vegetation (annual and perennial herbaceous vegetation (grasslands); low shrubby vegetation (garrigues); medium to high shrubby vegetation (maquis); arboreal vegetation) according to Otypková and Chytry (2006) and Dengler et al. (2009). We used a $1 \mathrm{~m} \times 1 \mathrm{~m}$ frame for herbaceous and a $2.5 \mathrm{~m} \times 2.5 \mathrm{~m}$ frame for low shrubby vegetation. For the high shrubby vegetation the same $2.5 \mathrm{~m} \times 2.5 \mathrm{~m}$ frame was used for each quadrant of the $25 \mathrm{~m}^{2}$ square. In the forest area the $100 \mathrm{~m}^{2}$ square was bounded by four poles and a rope and the abundance calculated based on the vertical projection for all species. In each relevé we recorded the cover area (with a tape-metric and a distance meter Leika DISTO тм D5 with $1 \mathrm{~mm}$ accuracy) of the different taxa and represented it in a 2D graphic model (field map). Also, the height of each plant was recorded using a tape-metric in the case of herbaceous and shrubby vegetation and with the distance meter Leika DISTO ${ }^{\mathrm{TM}}$ D5 for trees. Lastly, all field

Table 1

Landslide characteristics: morphometric parameters and location.

\begin{tabular}{|c|c|c|c|c|c|c|c|c|c|c|}
\hline \multirow[t]{2}{*}{ ID \# } & \multirow[t]{2}{*}{ Typology } & \multirow{2}{*}{$\begin{array}{l}\text { Max. Length } \\
(\mathrm{m})\end{array}$} & \multirow{2}{*}{$\begin{array}{l}\text { Max. Width } \\
(\mathrm{m})\end{array}$} & \multirow{2}{*}{$\begin{array}{l}\text { Slide area } \\
\left(\mathrm{m}^{2}\right)\end{array}$} & \multirow[t]{2}{*}{ Date } & \multirow{2}{*}{$\begin{array}{l}\text { Mean } \\
\text { slope }\left({ }^{\circ}\right)\end{array}$} & \multirow[t]{2}{*}{ Aspect } & \multirow{2}{*}{$\begin{array}{l}\text { Elevation } \\
(\mathrm{m})\end{array}$} & \multicolumn{2}{|l|}{ Land use "COS" } \\
\hline & & & & & & & & & 1990 & 2007 \\
\hline 1 & Shallow Translational Slide & 81 & 30 & 1804 & 2006 & 22 & $\mathrm{E}$ & $253-221$ & Pinewood forest & Sparse shrubs \\
\hline 2 & Shallow Rotational Slide & 73 & 64 & 3301 & 2006 & 26 & $\mathrm{E}$ & $249-213$ & High shrubs transition area & Sparse shrubs \\
\hline 3 & Shallow Translational Slide & 37 & 9 & 272 & $2006-2010^{\mathrm{a}}$ & 23 & W-NW & $233-223$ & Annual crops; Vineyard & Sparse shrubs \\
\hline 4 & Shallow Translational Slide & 40 & 67 & 1464 & $2006-2010^{a}$ & 27 & W-NW & $230-208$ & Mainly agricultural areas & Sparse shrubs \\
\hline 5 & Shallow Rotational Slide & 43 & 50 & 1219 & $1996-1997^{a}$ & 27 & NW-W & $193-176$ & Annual crops; Vineyard & Burned areas \\
\hline 6 & Shallow Rotational Slide & 42 & 33 & 937 & $1996-1997^{\mathrm{a}}$ & 28 & W & $197-176$ & Annual crops; Vineyard & Burned areas \\
\hline 7 & Shallow Translational Slide & 14 & 19 & 179 & 2010 & 36 & W & $165-158$ & Broadleaved forest & $\begin{array}{l}\text { Resinous and } \\
\text { broadleaved forest }\end{array}$ \\
\hline
\end{tabular}

a It was not possible to establish an absolute date of occurrence for these cases and only an estimated age is reported. 

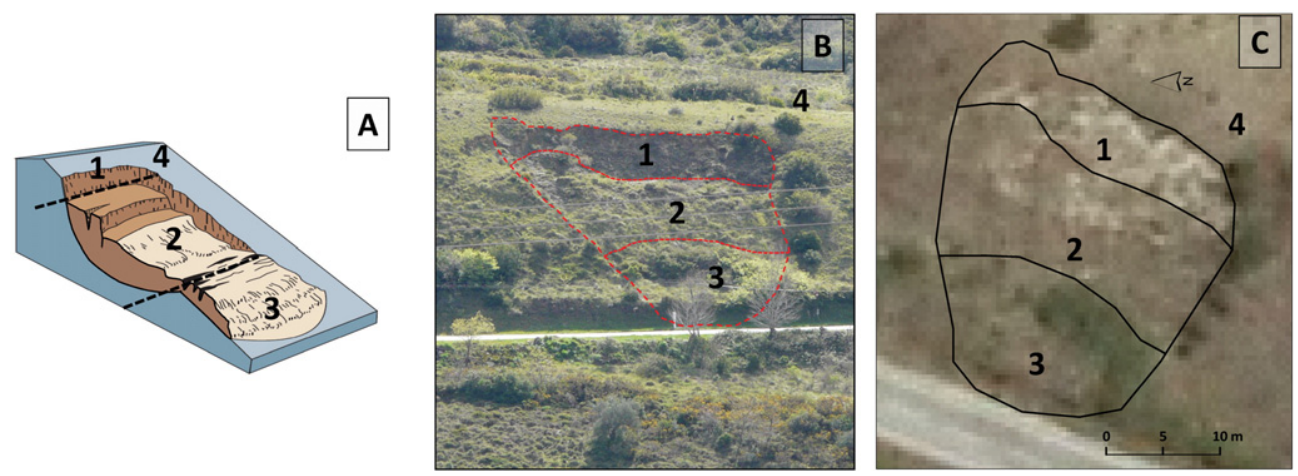

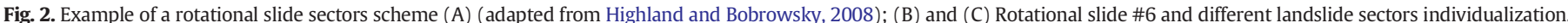

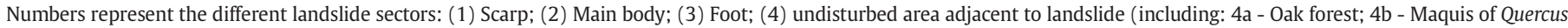
coccifera in mosaic with Brachypodium phoenicoides grasslands; $4 \mathrm{c}$ - Heathland in mosaic with Brachypodium phoenicoides grasslands; $4 \mathrm{~d}$ - Brachyopodium phoenicoides grasslands).

maps were vectored in ArcGis in order to calculate the percentage of study area occupied by each taxa within the square plot.

The dominance concept is used throughout the work in the sense of basal area (Begon et al., 2005; Kercher et al., 2009). Dominance and relative dominance of each species in a plot was obtained by Eqs. (1) and (2), respectively:

D.b.a. $=\frac{\text { b.a.for each taxa }}{\text { Area of the plot }} \times 100$

where D.b.a is the Dominance or proportional basal area in plots; and b.a. is basal area.

R.D.b.a. $=\frac{\text { D.b.a.for each taxa }}{\Sigma \text { dominance of all taxa }} \times 100$

where R.D.b.a. is the Relative Dominance or basal area.

The height of each species within a plot is the average height of all individuals. We used Eq. (3) to compute the average height of vegetation in each plot:

A.h.of vegetation in a plot

$$
=\sum_{\mathrm{i}=1}^{\mathrm{n}}\left(\frac{\text { R.D.b.a for each taxa }}{100} \times \text { A.h.for each taxa }\right)
$$

where A.h. is the Average height.

The total of 48 plots was submitted to a Non-metric multidimensional scaling (NMDS) with Bray-Curtis coefficient using CANOCO 5.5 software (Ter Braak and Šmilauer, 2012).

A polynomial regression based on landslide relevés (scarp, main body, foot) was made between floristic richness (in the sense of number of taxa) and the percentage of coverage for each plot. A Bartlett's test for homogeneity of variances was performed as was an ANOVA test (with the richness values).

We used the original classification of Raunkiær plant life-form (Raunkiær, 1934) subsequently revised and modified by BraunBlanquet (1964) and Mueller-Dombois and Ellenberg (2003): Phanerophytes - woody plants with resting buds $>50 \mathrm{~cm}$ or more above soil level (nanophanerophytes 0.5-2 m; microphanerophytes $2 \mathrm{~m}-8 \mathrm{~m}$; mesophanerophytes $8 \mathrm{~m}-30 \mathrm{~m}$; megaphanerophytes $>30 \mathrm{~m}$ high). Chamaephytes - woody plants with perennating buds borne between ground and $50 \mathrm{~cm}$ above the soil surface. Hemicryptophytes - herbaceous plants with buds at or near the soil surface. Cryptophytes - herbaceous plants resting buds lying either beneath the surface of the ground as a rhizome, bulb, corm, etc., or a resting bud submerged under water (geophytes resting in dry ground, helophytes resting in marshy ground, hydrophytes resting by being submerged under water. Therophytes annual seed plants.

Raunkiær plant life-forms classification (Raunkiær, 1934) was performed based on the abundance of each plant life-form in the scarp, in the main body, in the foot and in the group of Landslide Surrounding areas, respectively. We calculated the relative abundance of each plant life-forms for each sector using the following formula:

RaPLF $=\frac{\Sigma \text { dominance of each life form in the sector } \times 100}{\Sigma \text { dominance of all plant life forms in the sector }}$

where RaPLF is the Relative abundance of a Plant Life-Form within a sector.

We performed an indicator value (IndVal) analysis of the taxa present in the studied areas based on Table A2 (species in rows and samples in columns). IndVal method developed by Dufrêne and Legendre (1977) combines measurements (abundance and frequency of occurrence in samples assigned to each landslide strata) of the degree of specificity of a species to an ecological state. The IndVal of each taxa and the respective significance levels (performing 50,000 randomizations) were obtained using the "indval" function from "labdsv" package (Roberts, 2015), using R Statistical Software (R Core Team, 2015). IndVals were calculated and the results are shown in at Table A3 under supplemental material.

The nomenclature of vascular plants follows the works of Castroviejo (1986-2012), Franco (1971, 1984), Franco and Afonso (1994, 1998 , 2003). For the Orchydaceae family we follow Tyteca (1998) nomenclature. All specimens collected were identified in João de Carvalho e Vasconcellos Herbarium (Code: LISI) University of Lisbon, where all material is deposited.

Table 2

Distribution of the 48 relevés for each of the seven landslide environments.

\begin{tabular}{|c|c|c|c|c|c|c|c|}
\hline \multirow[b]{2}{*}{ Sample strata } & \multicolumn{3}{|c|}{ Landslide sectors } & \multicolumn{4}{|c|}{ Undisturbed area adjacent to landslide } \\
\hline & Scarp & $\begin{array}{l}\text { Main } \\
\text { body }\end{array}$ & Foot & $\begin{array}{l}\text { Oak forest of } \\
\text { Quercus } \\
\text { broteroi }\end{array}$ & $\begin{array}{l}\text { Maquis of Quercus coccifera in mosaic with } \\
\text { Brachypodium phoenicoides grasslands }\end{array}$ & $\begin{array}{l}\text { Heathland in mosaic with Brachypodium } \\
\text { phoenicoides grasslands }\end{array}$ & $\begin{array}{l}\text { Brachyopodium } \\
\text { phoenicoides grasslands }\end{array}$ \\
\hline \# relevés & 12 & 10 & 9 & 4 & 4 & 2 & 7 \\
\hline
\end{tabular}




\section{Results}

The analysis of the relevés from the different landslide sectors showed that there is a clear differentiation in the floristic composition, in the dominance of the Raunkiær plant life-form and in the seral stages between the different landslide sectors. Table A2 show the dominance or basal area of the taxa in the study area for all the relevés organized into the different strata according to the selected sampling design. The average plant cover in the landslide scarp plots has the lowest value of all sectors (26\%). The main landslide body reaches a much higher (67.6\%) average plant cover and the landslide foot has the highest value (97.7\%). There is a clear gradient between the highest and the lowest sectors of the landslide. Furthermore, the average height of the plants in the landslide scarp is the smallest of all sectors. Concerning the relationship between the average height and the percentage of vegetation cover Fig. 3 shows that the landslide scarp plots have the lowest values of coverage and the lower average height of the individuals.

Regarding the richness of floristic species, the plots in the landslide scarp have a lower number of taxa per plot (mean $=13.3$; variance 23.8 ) than the landslide main body ( mean $=19.8$; variance $=10.6$ ) and at the landslide foot the number of taxa per plot is lower again ( mean $=11.9$, Variance $=4.1$ ) (Fig. 4). Comparing the floristic species richness with the relative coverage for each plot, the lowest values of species richness are recorded in the landslide foot with higher coverage rates and the highest values of species richness are recorded in the landslide main body with medium coverage rates (Fig. 4). Similar pattern of floristic richness distribution within landslides had also been carried out by Velázquez and Gómez-Sal (2009) in a tropical dry climate in Nicaragua.

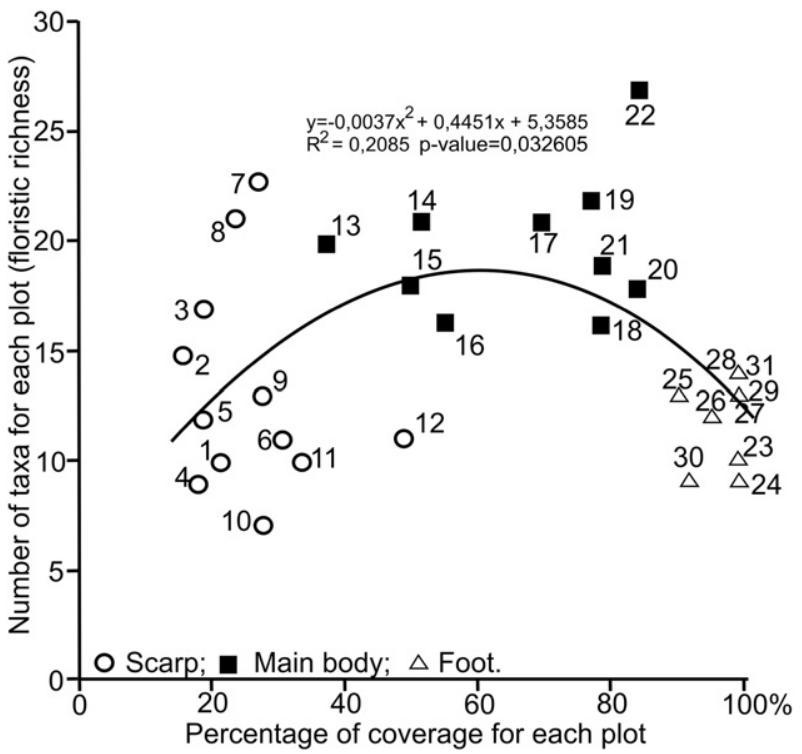

Fig. 4. Relationship between floristic richness and \% of coverage for plots included in landslide sectors. Bartlett's test for homogeneity of variances (floristic richness) with Pvalue $=0.049$ and ANOVA (floristic richness) with P-value $=0.00011925$.

The Non-metric multidimensional scaling (NMDS) of all the relevés clearly separated the three sectors of the landslides, based on their floristic composition (Fig. 5A and B). The landslide scarp is dominated by species characteristic of disturbed areas, ruderal areas and abandoned

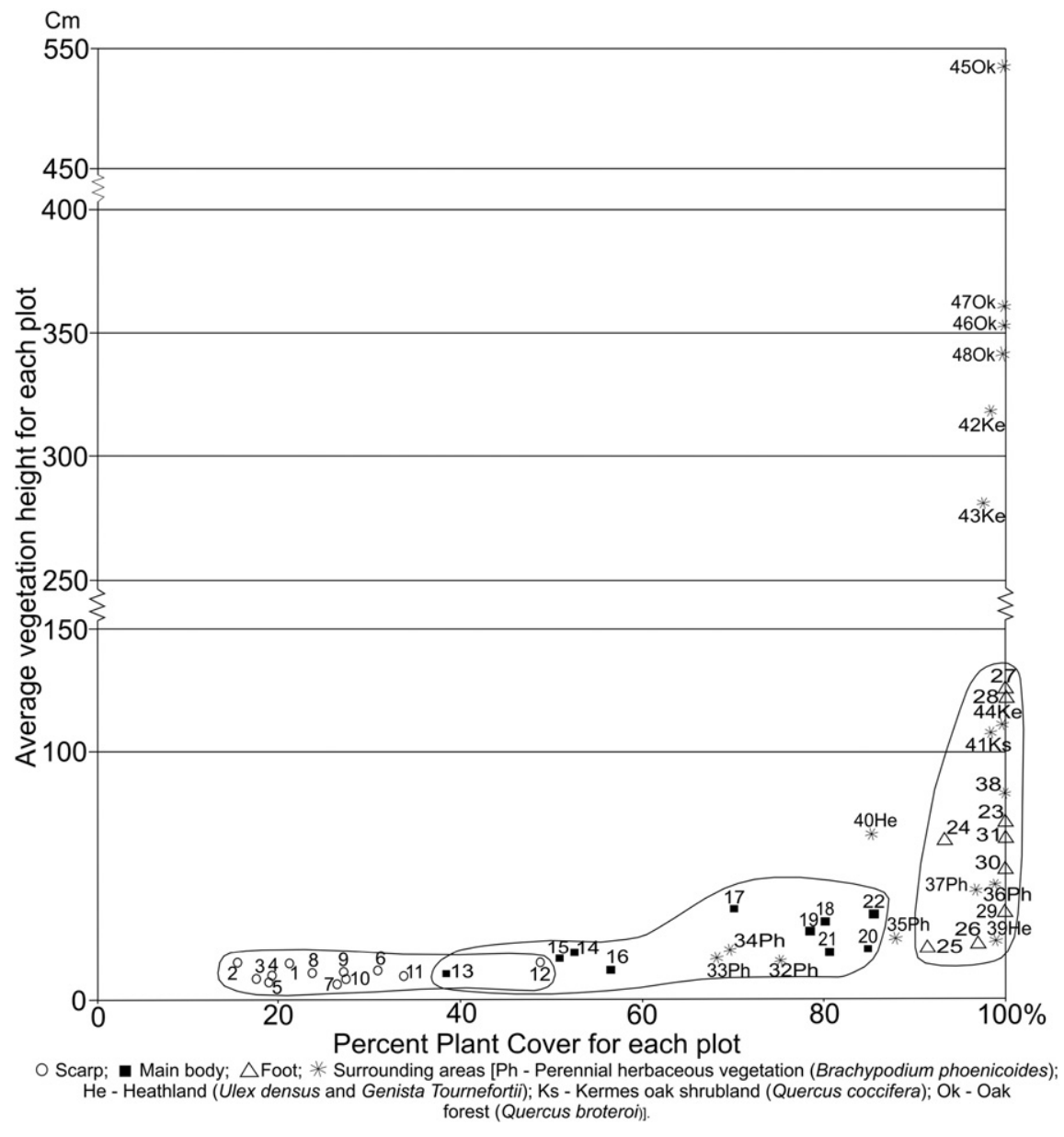

Fig. 3. Relationship between the average vegetation height and the coverage rate (percentage) for all plots. 

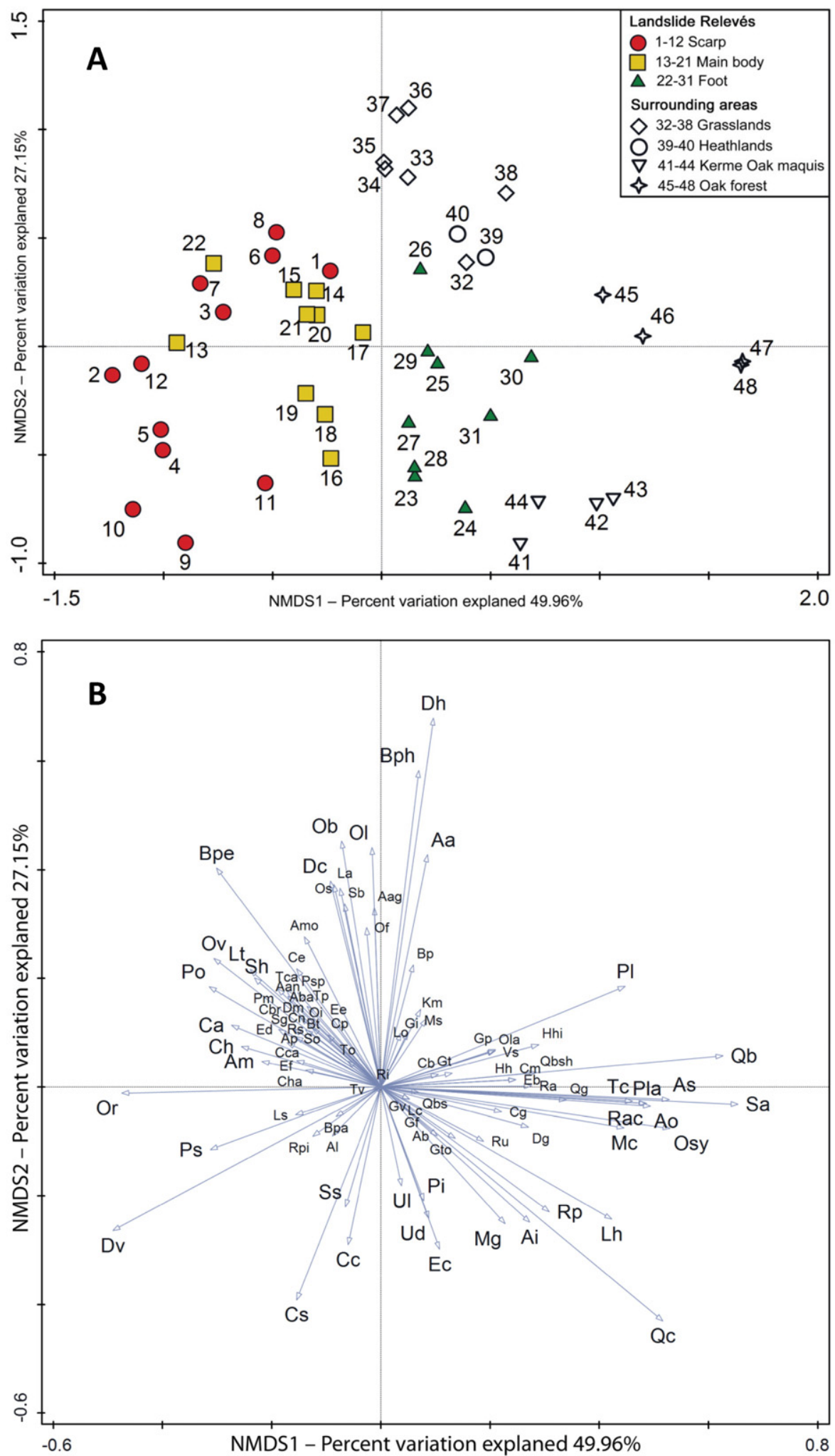

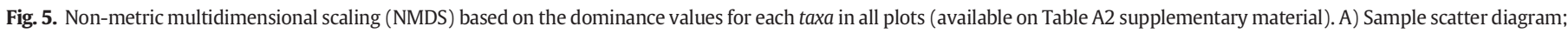
B) Species scatter diagram.

fields (91.22\%, Table 3) mainly herbaceous and subshrubs plants (75.6\%) belonging predominantly to Asteraceae, Fabaceae and Poaceae families. The Ononis ramosissima (Or), Phagnalon saxatile (Ps), Dittrichia viscosa (Dv), Pulicaria odora (Po), Blackstonia perfoliata (Bpe), Origanum virens (Ov), Carlina hispanica (Ch) and Anagallis monelli (Am) are the taxa more linked to the scarp (Fig. 5A, B and Table A3) reflecting the dominance of these species in the scarp relevés (Table 2). The percentage of the species group characteristic of disturbed areas, ruderal areas and abandoned fields is reduced to $72.95 \%$ in the landslide main body and to $12.57 \%$ in the landslide foot. Also the sum of herbaceous and subshrubs plants falls to $64.42 \%$ in the landslide main body and to $14.57 \%$ in the landslide foot. On the other hand, the percentage of climbers and 
bushes increases steadily from the landslide scarp to the landslide foot. Fig. 5B and Table 3 shows that the foot sector and the relevés from surrounding $Q$. coccifera maquis are close together and the taxa more linked to these two groups are medium to high scrubs and climbers (Pistacia lentiscus (Pi), Quercus coccifera (Qc), Rubia peregrina (Rp), Lonicera hispanica (Lh), Arum italicum (Ai). The relevés from Oak forest are positioned on the opposite side relatively to the scarp relevés in the axis 1 along which the communities are positioned from the basal communities in the scarp then the main body, the foot and finally the oak forest at the right end of the axis (Fig. 5A and B).

As the main regional indicator of strongly disturbed habitats, the Ononis ramosissima is common in the landslide main body and dominant in the landslide scarp. The Asteraceae, Poaceae and Fabaceae are the most represented families in the three landslide sectors. The Poaceae and Asteraceae (predominantly formed by heliophytic, thermophylic and oligotrophic species) show the highest percentage of coverage or dominance on the landslide scarp and declines dramatically towards the landslide main body and landslide foot where the increasing vegetation density and height does not allow for favorable light and temperature conditions. The Asteraceae plant family is one of the most common ones in landslides areas due to the great capacity for dispersal of most species (Dalling, 1994; Myster and Sarmiento, 1998; Shiels and Walker, 2003).

Concerning the Raunkiær plant life-form (Fig. 6) we observe that: i) concerning therophytes (annual plants) and hemicryptophytes the relative dominance is maximal on the landslide scarp and decreases towards the landslide foot; ii) the relative dominance of chamaephytes is maximal on the landslide main body; iii) there is a high relative dominance of climbing phanerophytes on the foot and the nano, micro and mesophanerophytes are absent on the landslide scarp and have a high relative dominance on the landslide foot; iv) the mesophanerophytes appear only in the landslide foot with a low relative dominance and are dominant on the undisturbed areas adjacent to landslide due to the presence of Oak forests.

Finally, our work demonstrates the importance of the landslides as biodiversity reservoirs. Table 4 shows the presence of orchids in the studied landslides. However, the abundance of orchids is higher in the landslide main body, lower in the landslide scarp and absent in the landslide foot. Regarding the undisturbed area adjacent to landslide the orchids survive only in the perennial grasslands, but less abundantly than in the landslide areas.

\section{Discussion}

\subsection{Flora, vegetation and seral stage differences between landslide sectors}

Given that the studied landslides have similar ages and based on the above mentioned differentiation between different landslide sectors it can be stated that there is a clear gradient in the seral vegetation stage from the landslide scarp to the landslide foot.

The landslide scarp usually displays the $\mathrm{C}$ horizon (mineral horizon) at the surface and consequently has extreme conditions concerning nutrients, moisture and stability, which evolve very slowly allowing a sluggish development of the vegetation (Beguería, 2006). That fact may explain in the case of the landslide scarp the lowest percentage of plant coverage or dominance, the lowest average height of the vegetation and a clear dominance of taxa characteristic of anthropic perturbed habitats (Table 3). The latter regionally occurs in habitats created by anthropogenic disturbances such as road embankments, clear cuts and construction zones that provides habitats similar to landslides (specially the scarp and main body) (Walker and Shiels, 2013). The occurrence of chamaephytic to nanophanerophytic scrubs in the landslide scarp (Fig. $5 \mathrm{~A}$ and $\mathrm{B}$ ), although rare, is possibly related to the permanence of parts of the radicular system of these plants on the $C$ horizon which was cut during the mass movement. The recorded highest relative dominance of annual plants (therophytes) in the landslide scarp is possibly due to extreme ecological conditions, mainly dryness and high temperatures during the dry season.

The landslide main body is the store area of the soil that moves downslope from the landslide scarp. In this case the amount of propagules (roots, rhizomes, bulbs) that are moved with the soil mass could be very significant which facilitates the rapid development of the small shrubs (chamaephytes) (Table 3). For relatively recent landslides of approximately the same age it is clear that the vegetation attains a later succession stage in the landslide main body than in the landslide scarp (in early succession stages). This difference may be explained by the presence of a large number of fissures (tension cracks) in the soil of the landslide main body zone as a consequence of differential deformation patterns associated to the main rotational soil rupture. These fissures facilitate the infiltration of air and water into the soil (Novák et al., 2000) and according to the work of Song et al. (2012) it accelerates vegetation recovery. This may explain the increasing dominance of plants of the Fabaceae family belonging to Ulex and Genista genus, from the landslide scarp to the landslide main body which increases again towards the landslide foot (Ulex densus, Ulex latebracteatus and Genista tournefortii) (Table A3). The Fabaceae family is known for their ability to fix atmospheric nitrogen through $\mathrm{N}$-fixing nodules (Thomas and Spurway, 2001; Kraus et al., 2003; Gupta and Mukerji, 2006; Schaetzl and Thompson, 2015). Nodulation was found to require well aerated media while poor aeration in the soil inhibited nodule formation (Thomas and Spurway, 2001). According to Walker and Shiels (2013) nodular nitrogen fixing symbionts colonize landslides frequently and they are less numerous on other types of primary succession (Walker, 1993).

The high dominance of grasses (mainly B. phenicoides and $D$. hispanica) on the landslide scarp (21.1\%) and landslide main body (21.4\%) of the studied landslides is in line with the values obtained by other authors (Walker and Boneta, 1995; Myster and Sarmiento, 1998; Restrepo and Vitousek, 2001; Velázquez and Gómez-Sal, 2009; Elias and Dias, 2009) and may be related with the ability of these plants to rapidly colonize disturbed habitats and dominate landslides for several years after landslide occurrence. Several studies show that when the disturbance exceeds the tolerance threshold of sprouters, seeders have an advantage because of their higher growth rates and their greater colonization capacity (Vesk and Westoby, 2004; Guerrero-Campo et al., 2006). Perennial grasses like B. phenicoides and $D$. hispanica have a fasciculate root system with a higher fine-root density that maximizes the capacity of water and nutrient uptake (Kummerow, 1981; Fitter, 1991; Caldwell and Richards, 1986). In Mediterranean climates this kind of root structure has a particular advantage (Canadell and Zedler, 1994) because of the irregularity of the precipitation and of the characteristics of the landslide scarp and main body which facilitates the drainage and promotes dryness. The fasciculate root system of the grasses also allows for greater stability of the plant, which is particularly important in the scarp, and further provides soil stabilization and decreases the risk of erosion (Velázquez and Gómez-Sal, 2009).

In regard to successional processes, the landslide foot clearly appears as the most evolved sector. The fact that it could receive a large amount of material slipped with propagules allows a rapid development of the aerial part of the shrubs that reach total coverage of the soil after 15 years. The occurrence of the water table near the surface is also important for the rapid development of shrubs due to the water that infiltrates in the soil fissures at the landslide main body, and also to weak slope that facilitates the water accumulation. This may explain the presence of mesophilic species like Prunus insititioides and especially the high dominance of hygrophilous such as Rubus ulmifolius (Fig. 6). The frequent occurrence of vines ( $0.89 \%$ on landslide scarp, $1.41 \%$ on the landslide main body and $6.31 \%$ on the landslide foot) indicates that we are on a pre-forest environment. On the other hand, the landslide foot is also characterized by the presence of middle-sized shrubs Quercus coccifera, Daphne gnidium, Myrtus communis, Ulex latebracteatus which become 
Table 3

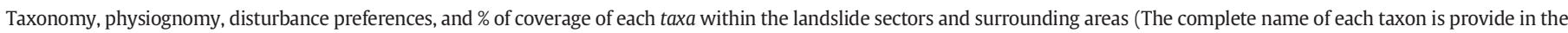
supplemental dominance Table A2).

\begin{tabular}{|c|c|c|c|c|c|c|c|c|c|c|}
\hline & \multirow{3}{*}{ 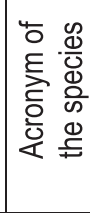 } & & \multicolumn{4}{|c|}{ Landslide (b) } & \multicolumn{4}{|c|}{ Surrounding areas (b) } \\
\hline & & & \multirow[b]{2}{*}{ (a) } & Scarp & $\begin{array}{l}\text { Main } \\
\text { body }\end{array}$ & Foot & $\begin{array}{c}\text { Oak } \\
\text { forest }\end{array}$ & $\begin{array}{l}\text { Maquis Q. } \\
\text { coccifera }\end{array}$ & Garrigue & Grasslands \\
\hline & & & & \multicolumn{3}{|c|}{$\%$ of total coverage } & \multicolumn{4}{|c|}{$\%$ of total coverage } \\
\hline Ononis ramosissima & Or & Leguminosae & Sub & 26.99 & 17.03 & 0.30 & 0.00 & 0.00 & 0.00 & 0.02 \\
\hline Cistus salvifolius & Cs & Cistaceae & Sh & 12.57 & 5.39 & 1.28 & 0.00 & 1.23 & 0.00 & 0.00 \\
\hline Dittrichia viscosa & Dv & Asteraceae & Sh & 5.16 & 0.00 & 0.10 & 0.03 & 0.00 & 0.00 & 0.00 \\
\hline Phagnalon saxatile & Ps & Asteraceae & $\mathrm{He}$ & 2.37 & 0.06 & 0.00 & 0.00 & 0.00 & 0.00 & 0.00 \\
\hline Carex hallerana & Cha & Cyperaceae & $\mathrm{He}$ & 1.79 & 0.94 & 0.00 & 0.00 & 0.00 & 0.00 & 0.00 \\
\hline Antirrhinum linkianum & $\mathrm{Al}$ & Plantaginaceae & $\mathrm{He}$ & 0.91 & 0.00 & 0.00 & 0.15 & 0.00 & 0.00 & 0.00 \\
\hline Polygala monspeliaca & $\mathrm{Pm}$ & Polygalaceae & $\mathrm{He}$ & 0.68 & 0.00 & 0.00 & 0.00 & 0.00 & 0.00 & 0.05 \\
\hline Reichardia picroides & Rpi & Asteraceae & $\mathrm{He}$ & 0.63 & 0.17 & 0.01 & 0.00 & 0.22 & 0.00 & 0.00 \\
\hline Origanum virens & Ov & Lamiaceae & $\mathrm{He}$ & 0.63 & 0.42 & 0.01 & 0.00 & 0.00 & 0.21 & 0.11 \\
\hline Trisetaria panicea & Tp & Poaceae & $\mathrm{He}$ & 0.24 & 0.00 & 0.00 & 0.00 & 0.00 & 0.09 & 0.01 \\
\hline Salvia sclareoides & Ss & Lamiaceae & $\mathrm{Sh}$ & 0.22 & 0.18 & 0.00 & 0.00 & 0.19 & 0.00 & 0.00 \\
\hline Eryngium dilatatum & Ed & Apiaceae & $\mathrm{He}$ & 0.13 & 0.00 & 0.00 & 0.00 & 0.00 & 0.00 & 0.00 \\
\hline Klasea monardii & $\mathrm{Km}$ & Asteraceae & $\mathrm{He}$ & 0.02 & 0.00 & 0.01 & 0.00 & 0.00 & 0.02 & 0.00 \\
\hline Centranthus calcitrapae & Cc & Valerianaceae & $\mathrm{He}$ & 0.02 & 0.00 & 0.00 & 0.00 & 0.00 & 0.00 & 0.00 \\
\hline Pulicaria odora & Po & Asteraceae & $\mathrm{He}$ & 4.72 & 1.53 & 0.00 & 0.00 & 0.02 & 0.00 & 0.74 \\
\hline Dactylis hispanica & $\mathrm{Dh}$ & Poaceae & $\mathrm{He}$ & 4.17 & 2.77 & 1.22 & 0.00 & 0.09 & 27.93 & 44.59 \\
\hline Daucus carota & Dc & Apiaceae & $\mathrm{He}$ & 3.55 & 0.65 & 0.21 & 0.13 & 0.11 & 0.00 & 2.06 \\
\hline Centaurium erythraea & $\mathrm{Ce}$ & Gentianaceae & $\mathrm{He}$ & 1.32 & 0.05 & 0.04 & 0.00 & 0.00 & 0.00 & 0.36 \\
\hline Blackstonia perfoliata & Bpe & Gentianaceae & $\mathrm{He}$ & 1.04 & 0.18 & 0.00 & 0.00 & 0.00 & 0.00 & 0.19 \\
\hline Bellis perennis & $B p$ & Asteraceae & $\mathrm{He}$ & 0.04 & 0.00 & 0.00 & 0.00 & 0.00 & 0.00 & 0.15 \\
\hline Sanguisorba balearica & $\mathrm{Sb}$ & Rosaceae & $\mathrm{He}$ & 0.38 & 0.17 & 0.01 & 0.00 & 0.01 & 0.00 & 0.22 \\
\hline Leontodon taraxacoides & Lt & Asteraceae & $\mathrm{He}$ & 0.12 & 0.05 & 0.00 & 0.00 & 0.01 & 0.00 & 0.04 \\
\hline Achillea ageratum & Aag & Asteraceae & $\mathrm{He}$ & 0.10 & 0.00 & 0.00 & 0.00 & 0.00 & 0.00 & 0.14 \\
\hline Anagallis monelli & Amo & Primulaceae & $\mathrm{He}$ & 0.72 & 0.58 & 0.03 & 0.00 & 0.00 & 0.01 & 0.38 \\
\hline Carlina hispanica & Ch & Asteraceae & $\mathrm{He}$ & 0.10 & 0.01 & 0.01 & 0.00 & 0.01 & 0.00 & 0.01 \\
\hline Brachypodium phoenicoides & Bph & Poaceae & $\mathrm{He}$ & 16.70 & 18.56 & 11.70 & 1.18 & 1.22 & 0.00 & 33.70 \\
\hline Sideritis hirsuta & Sh & Lamiaceae & Sub & 5.34 & 10.67 & 0.15 & 0.00 & 0.01 & 0.00 & 1.20 \\
\hline Asparagus aphyllus & $\mathrm{Aa}$ & Asparagaceae & Sh & 0.03 & 0.27 & 0.01 & 0.13 & 0.28 & 0.00 & 1.41 \\
\hline Lathyrus angulatus & La & Fabaceae & Sc & 0.01 & 0.12 & 0.00 & 0.00 & 0.00 & 0.01 & 0.09 \\
\hline Ophrys scolopax & Os & Orchidaceae & $\mathrm{He}$ & 0.05 & 0.10 & 0.00 & 0.00 & 0.00 & 0.00 & 0.12 \\
\hline Aceras anthropophorum & Aan & Orchidaceae & $\mathrm{He}$ & 0.06 & 0.07 & 0.00 & 0.00 & 0.00 & 0.00 & 0.03 \\
\hline Taraxacum obovatum & To & Asteraceae & $\mathrm{He}$ & 0.06 & 0.07 & 0.00 & 0.00 & 0.00 & 0.00 & 0.05 \\
\hline Pallenis spinosa & Psp & Asteraceae & $\mathrm{He}$ & 0.00 & 0.02 & 0.00 & 0.00 & 0.00 & 0.00 & 0.01 \\
\hline Genista tounefortii & Gt & Fabaceae & Sh & 2.32 & 20.88 & 13.05 & 0.22 & 2.61 & 47.82 & 0.00 \\
\hline Trifolium campestre & Tca & Fabaceae & $\mathrm{He}$ & 0.16 & 1.44 & 0.00 & 0.00 & 0.00 & 0.00 & 0.24 \\
\hline Linum strictum & Ls & Linaceae & $\mathrm{He}$ & 0.81 & 1.27 & 0.00 & 0.00 & 0.00 & 0.00 & 0.03 \\
\hline Orchis italica & Oi & Orchidaceae & $\mathrm{He}$ & 0.05 & 0.74 & 0.00 & 0.00 & 0.00 & 0.00 & 0.04 \\
\hline Anacamptis pyramidalis & Ap & Orchidaceae & $\mathrm{He}$ & 0.13 & 0.58 & 0.00 & 0.00 & 0.00 & 0.00 & 0.04 \\
\hline Bupleurum paniculatum & Bpa & Apiaceae & $\mathrm{He}$ & 0.38 & 3.86 & 0.01 & 0.00 & 0.00 & 0.15 & 0.07 \\
\hline Convolvulus althaeoides & $\mathrm{Ca}$ & Convolvulaceae & $\mathrm{He}$ & 0.60 & 0.61 & 0.00 & 0.02 & 0.08 & 0.08 & 0.00 \\
\hline Pistacia lentiscus & $\mathrm{PI}$ & Anacardiaceae & Sh & 0.00 & 0.28 & 0.00 & 3.51 & 3.49 & 9.03 & 4.74 \\
\hline Avena barbata & Aba & Poaceae & $\mathrm{He}$ & 0.00 & 0.09 & 0.00 & 0.00 & 0.00 & 0.03 & 0.00 \\
\hline Mantisalca salmantica & Ms & Asteraceae & Sub & 0.00 & 0.05 & 0.03 & 0.02 & 0.00 & 9.06 & 0.00 \\
\hline Elaeoselinum foetidum & Ef & Apiaceae & $\mathrm{He}$ & 0.00 & 0.24 & 0.00 & 0.00 & 0.00 & 0.00 & 0.00 \\
\hline Daucus muricatus & Dm & Apiaceae & $\mathrm{He}$ & 0.00 & 0.23 & 0.00 & 0.00 & 0.00 & 0.00 & 0.00 \\
\hline Anthyllis maura & Am & Fabaceae & $\mathrm{He}$ & 0.26 & 0.38 & 0.00 & 0.00 & 0.00 & 0.00 & 0.00 \\
\hline Carduus broteroi & $\mathrm{Cbr}$ & Asteraceae & $\mathrm{He}$ & 0.00 & 0.11 & 0.00 & 0.00 & 0.00 & 0.00 & 0.00 \\
\hline Rosa sempervirens & Rs & Rosaceae & Sc & 0.00 & 0.08 & 0.00 & 0.00 & 0.00 & 0.00 & 0.00 \\
\hline Centaurea pullata & $\mathrm{Cp}$ & Asteraceae & $\mathrm{He}$ & 0.06 & 0.08 & 0.00 & 0.00 & 0.00 & 0.00 & 0.00 \\
\hline Thapsia villosa & Tv & Apiaceae & $\mathrm{He}$ & 0.05 & 0.07 & 0.00 & 0.00 & 0.05 & 0.00 & 0.00 \\
\hline Hyacinthoides hispanica & Hhi & Asparagaceae & $\mathrm{He}$ & 0.00 & 0.07 & 0.00 & 0.37 & 0.09 & 0.00 & 0.14 \\
\hline Bartsia trixago & $\mathrm{Bt}$ & Orobanchaceae & $\mathrm{He}$ & 0.00 & 0.06 & 0.00 & 0.00 & 0.00 & 0.00 & 0.00 \\
\hline Ophrys bombyliflora & $\mathrm{Ob}$ & Orchidaceae & $\mathrm{He}$ & 0.00 & 0.06 & 0.00 & 0.00 & 0.00 & 0.00 & 0.00 \\
\hline Stachys ocymastrum & So & Lamiaceae & $\mathrm{He}$ & 0.00 & 0.05 & 0.00 & 0.00 & 0.00 & 0.00 & 0.00 \\
\hline
\end{tabular}




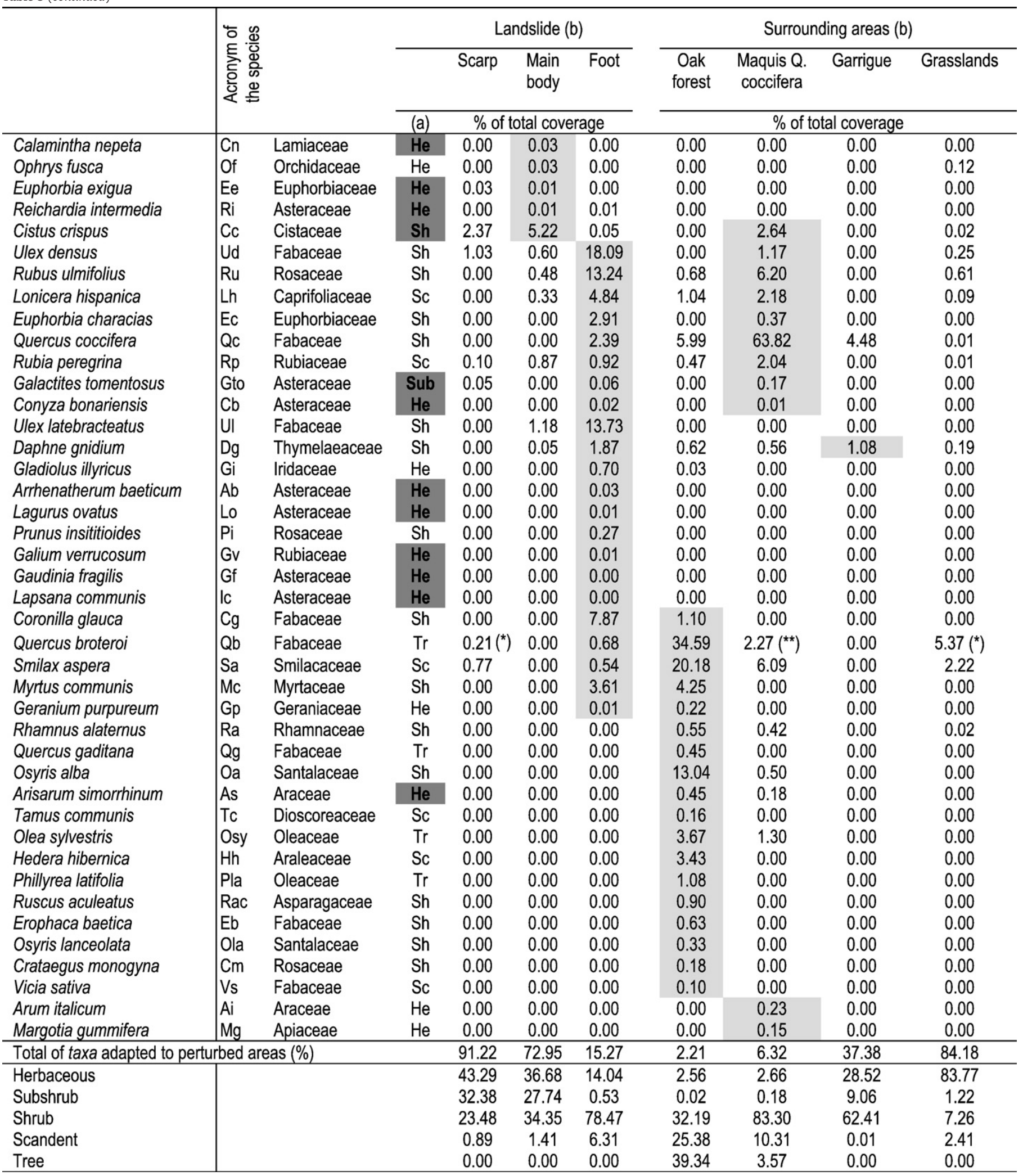

Sh - shrub; Sub - subshrub; Sc - scandent; He - herbaceous; Tr - Tree. (a) - squares in dark gray correspond to taxa adapted to perturbed areas (ruderal species - species characteristics of

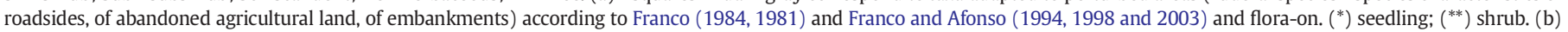
squares in light gray correspond to highest values of relative dominance of each sector.

dominant and higher in the adjacent maquis (Table A3). The mesophanerophytes do not occur in the studied landslides because a maximum of 20 years has elapsed since the occurrence of the landslides which is not long enough for the development of forests.

\subsection{The floristic and physiognomic differences between landslide sectors}

The floristic and physiognomic-structural differences between the vegetation in the three landslide sectors, evidenced by this work, and 

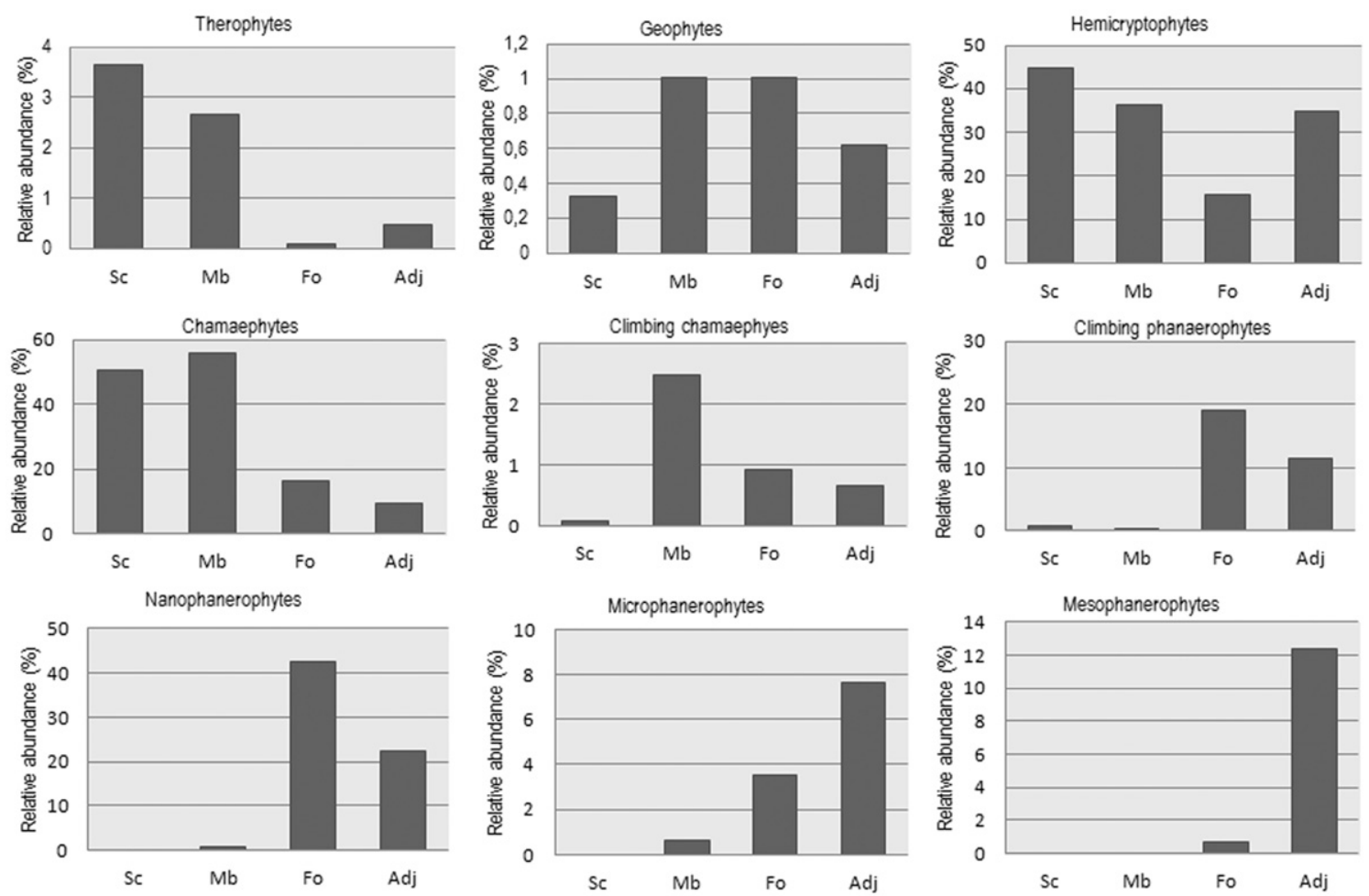

Fig. 6. Raunkiær plant life-forms (sc - Scarp; Mb - Main body; Fo - Foot; Adj - Landslide surrounding areas.

between these and the undisturbed areas adjacent to the landslide justify the excellent separation between groups shown by the NMDS (Fig. 5A and B). The analysis of Fig. 4 show a spatial organization of the plots following a gradient of perturbation intensity which is subjacent to the differences found in structure and chemical composition of the soil by Guariguata (1990) and Wilcke et al. (2003) among others authors (Lundgren, 1978; Adams and Sidle, 1987; Reddy and Singh, 1993; Zarin and Johnson, 1995a, 1995b; Fetcher et al., 1996; Claessens et al., 2006; Shiels et al., 2008; Shiels and Walker, 2013), according to which the lower zone of the landslide (the foot) had higher concentrations of carbon, total organic nitrogen and exchangeable cations than the upper zone.

Based on floristic composition the NMDS shows a clear difference between landslide plots and surrounding areas. Plots in the landslide scarp are separated based on the dominance of species that are characteristic of ruderal and perturbed habitats (Fig. 5B and Table A3). The dominant species in this group is Ononis ramosissima (species with wide distribution in Iberia and in parts of the Mediterranean ruderal areas, strongly disturbed habitats or even nitrophilous) and the second dominant species is Brachypodium phoenicoides. Due to its ability to colonize extreme environments (in relation to disturbance and nutrients) Ononis ramosissima is usually the dominant species on cut/fill slopes and is a major bioindicator of landslides due to its high dominance on the scarp and main body of the landslides (Table 3, A2 and A3). However, there are no landslides "specialists" in the sense of species exclusive to landslides (Walker and Shiels, 2013).

In the landslide main body the dominant species is Genista tounefortii and the second dominant is Brachypodium phoenicoides. The coverage of Brachypodium phoenicoides is greater in the landslide main body; however, the complex of microhabitats that characterized the landslide main body allows an abundance of medium-sized shrubs in contrast to the undisturbed area adjacent to landslide where we

Table 4

Presence and Abundance of Orchidaceae in all plots.

\begin{tabular}{|c|c|c|c|c|c|c|c|c|c|c|c|c|c|}
\hline & \multicolumn{7}{|l|}{ Landslide } & \multicolumn{6}{|c|}{ Surrounding areas } \\
\hline & \multicolumn{3}{|l|}{ Scarp } & \multicolumn{3}{|l|}{ Main body } & \multirow[t]{2}{*}{ Foot } & \multicolumn{3}{|c|}{ Perennial grassland } & \multirow[t]{2}{*}{ Heathland } & \multirow{2}{*}{$\begin{array}{l}\text { Kerme } \\
\text { oak }\end{array}$} & \multirow{2}{*}{$\begin{array}{l}\text { Oak } \\
\text { forest }\end{array}$} \\
\hline & $\begin{array}{l}\text { Presence } \\
\left({ }^{*}\right)\end{array}$ & $\begin{array}{l}\text { Presence } \\
\%\end{array}$ & Abundance & $\begin{array}{l}\text { Presence } \\
\left({ }^{*}\right)\end{array}$ & $\begin{array}{l}\text { Presence } \\
\%\end{array}$ & Abundance & & Presence $\left({ }^{*}\right)$ & $\begin{array}{l}\text { Presence } \\
\%\end{array}$ & Abundance & & & \\
\hline Orchis italica & 2 & 16.67 & 0.01 & 5 & 50 & 0.52 & 0 & 2 & 28.57 & 0.06 & 0 & 0 & 0 \\
\hline $\begin{array}{l}\text { Anacamptis } \\
\text { pyramidalis }\end{array}$ & 1 & 8.33 & 0.03 & 5 & 50 & 0.41 & 0 & 3 & 42.86 & 0.06 & 0 & 0 & 0 \\
\hline Ophrys scolopax & 2 & 16.67 & 0.01 & 5 & 50 & 0.07 & 0 & 4 & 57.14 & 0.16 & 0 & 0 & 0 \\
\hline Ophrys lutea & 0 & 0.00 & 0.00 & 4 & 40 & 0.04 & 0 & 4 & 57.14 & 0.15 & 0 & 0 & 0 \\
\hline Ophrys fusca & 0 & 0.00 & 0.00 & 2 & 20 & 0.02 & 0 & 2 & 28.57 & 0.16 & 0 & 0 & 0 \\
\hline Ophrys bombyliflora & 0 & 0.00 & 0.00 & 3 & 30 & 0.04 & 0 & 4 & 57.14 & 0.00 & 0 & 0 & 0 \\
\hline $\begin{array}{l}\text { Aceras } \\
\text { anthropophorum }\end{array}$ & 1 & 8.33 & 0.02 & 4 & 40 & 0.05 & 0 & 1 & 14.29 & 0.05 & 0 & 0 & 0 \\
\hline
\end{tabular}

$\left({ }^{*}\right)$ Number of times that the taxon occurs in all relevés. 
can see a clearly spatial segregation between the heathlands (Ulex sp. and Genista sp.) and the grasslands (Brachypodium) that correspond to different successional stages. In the landslide main body heathlands and grasslands do not have a distinct spatial separation and occur together.

Finally, plots from the landslide foot are colonized by Ulex densus and Ulex latebracteatus as the first and second dominant species respectively and also a high dominance of vines and shrubs characteristic of the surroundings maquis. Fig. 5A shows that (out of all the landslide sectors) the records pertaining to the landslide foot are the ones closest to the corresponding groups in undisturbed area adjacent to landslides.

Despite the discussion about the relationship between disturbance regimes and species diversity and some criticism about Intermediate Disturbance Hypothesis (IDH) (Mackey and Currie, 2001; Hall et al., 2012; Fox, 2013) our work shows a tendency for peaked, unimodal diversity-disturbance relationships (DDRs) (Fig. 4) according to the model originally described by Connell (1978). Despite the meta- analysis of empirical disturbance studies conducted by Mackey and Currie (2001) according to which many different patterns of variation in community diversity across disturbance gradients can be observed in nature, (increasing, decreasing, and U-shaped DDRs (Mackey and Currie, 2001), Fig. 4 shows clearly that floristic richness rises from the landslide scarp to the landslide main body and falls to the landslide foot. It is true that the three landslide sectors were subject to a disturbance process; however, the intensity (from the vegetation point of view) is maximal on the landslide scarp and decreases to the base of the landslide. So the floristic diversity is minimal on the landslide scarp where the extreme conditions limit the competition. In the landslide foot a dense and high shrub community totally covers this sector and the floristic richness is low. In the landslide main body, the intermediate levels of disturbance (within the landslide) diversity is thus maximized because species that thrive at both early and late successional stages can coexist (Wilkinson, 1999; Kricher, 2011; Catford et al., 2012).

It is interesting to note that there is a significant difference in the variance values (obtained in the ANOVA analysis) between the three sectors of the landslides: i) scarp 23.8409; ii) main body 10.6222; iii) foot 4.1111. The plots in the landslide foot have similar floristic richness (all the values are low) while the landslide scarp has a high variance consistent with the diversity of situations found between the scarps. Depending on the magnitude of the landslide, among other factors, the landslide scarp may exhibit, or not, the mineral horizon on the surface and there is a set of situations between these two extremes.

\subsection{The importance of landslides as biodiversity reservoirs}

Orchids are documented as colonists of tropical landslides (Dalling, 1994; Myster and Sarmiento, 1998; Shiels et al., 2008; Walker et al., 2010). In the Mediterranean region and in calcicolous soils (neutrophillous to basophilous) within perturbed areas mostly due to abandoned cereals crops, orchids are abundant, justifying the high value for protection and conservation of these dry grasslands (Festuco-Brometalia). In some way the scarp and main body of landslides in calcicolous areas occupied by perennial grasslands are favorable to the successful establishment of orchids that subsist here in higher numbers than in adjacent perennial grasslands. The perennial grassland dominated by Brachypodium phoenicoides is a habitat of Natura 2000 Network (6210 Semi-natural dry grasslands and scrubland facies on calcareous substrates (Festuco-Brometalia) ( ${ }^{*}$ important orchid sites) (EC, 2007; JNCC et al., 2007). The habitat is considered a priority type $\left(6210^{*}\right)$, only if it is an important orchid site (EC, 2007) (Calaciura and Spinelli, 2008; Cruz and Espirito-Santo, 1999). In the case of the studied areas, the first condition to consider the orchids as typical of $6210^{*}$ is achieved as the test sites host a rich suite of orchid species (Table 4, EC, 2007). Therefore, we can state that the main body of the studied landslides (Mediterranean climate with soils derived from limestones) colonized by perennial grasslands are included in the habitat 6210 , priority protection subtype $6210^{*}$ due to the high richness in orchids. The perennial grasslands in surrounding areas (dominated by Brachipodium phoenicoides) belong to the same subtype (6210*) although the orchid richness is higher in the landslide main body than in the perennial grassland of the undisturbed area adjacent to landslide. It should also be noted that due to the cyclic reactivation of some landslides north of Lisbon (Zêzere et al., 2015; Oliveira et al., 2015) the constant mobilization of the soil mass fosters the existence of a dynamic equilibrium between the landslide main body vegetation and the disturbance frequency, and consequently promotes the maintenance of the habitat conditions favorable to orchid colonization. On the contrary, in the undisturbed area adjacent to the landslide the Brachypodium grassland that are favorable to orchid colonization result from agricultural abandonment and undergo a successional process with the development of a low scrub stage followed by a high shrubby step and the orchids are not able to establish. The orchid species are supplanted by more vigorous plants at locations with plenty of water and nutrients (LIFE2002/NAT/D/8461). The abandonment of traditional agriculture and grazing in the Mediterranean region is creating unfavorable conditions for Orchidaceae (Crofts and Jefferson, 1999). This situation is forcing the authorities to draw up management plans to create habitats favorable to orchids in order to offset observed declines. A critical factor in the long-term maintenance of an orchid population is the maintenance of conditions conducive to germination and establishment (CFA, 2007; Pihl et al., 2001).

\section{Conclusions}

Our work demonstrates that there is a clear distinction between the landslide scarp, main body and foot concerning floristic composition, vegetation structure, floristic richness, functional types and seral stage in succession process. Despite the inexistence of a flora exclusive of landslides we demonstrated that there is a package of species that are characteristic of each landslide sector. Concerning the florist composition, we can conclude that for the same seral stage (in terms of structural and physiognomic characteristics) the floristic composition of the landslide plots is not the same as in the surrounding areas. This conclusion is especially valid for the landslide scarp and landslide main body and is due to the fact that the mass movement promotes significant modifications in soil structure (lasting for several decades) that does not occur in the surrounding areas. The successional process in the surrounding areas depends on the agricultural and grazing activities as well as on the frequency of wildland fires. We demonstrated that landslides in limestone's areas with a Mediterranean climate are an important reservoir of biodiversity mainly for Orchidaceae (priority habitat of Natura 2000 Network) and should be considered as protected areas. Simultaneously with management programs to create favorable habitats to the Mediterranean orchids, the protection of some landslides in limestone areas is a good and inexpensive alternative to the maintenance of these populations.

Supplementary data related to the communities of Portuguese oak forest series (Arisaro clusi-Querceto broteroi sigmetum) and related bioindicators that make up the regional natural vegetation of the studied territory is included in Table A1. The dominance or basal area of the taxa in the study area organized into the different landslides strata according to the selected sampling design can be found in Table A2. The indicator value (IndVal) analysis of the taxa present in the studied areas based on Table A1 is included in Table A3. Supplementary data associated with this article can be found in the online version, at http://dx. doi.org/10.1016/j.scitotenv.2016.09.119.

\section{Acknowledgments}

This work was supported by the project FORLAND Hydrogeomorphologic risk in Portugal: driving forces and application 
for land use planning [PTDC/ATPGEO/1660/2014] which was financed by the Portuguese Foundation for Science and Technology (FCT). SC Oliveira was funded by a Post-doctoral grant [SFRH/BPD/85827/2012] from the Portuguese Foundation for Science and Technology (FCT).

\section{References}

Adams, P.W., Sidle, R.C., 1987. Soil conditions in three recent landslides in Southeast Alaska. Forest Ecol. Manag. 18 (2), 93-102.

Begon, M., Townsend, C.R., Harper, J.L., 2005. Ecology: From Individuals to Ecosystems. 4th Ed. Wiley-Blackwell, Oxford.

Beguería, S., 2006. Changes in land cover and shallow landslide activity: a case study in the Spanish Pyrenees. Geomorphology 74, 196-206.

Braun-Blanquet, J., 1964. Pflanzensoziologie, Grundzüge der Vegetationskunde. 3. Auflage. Springer-Verlag, Wien.

Calaciura, B., Spinelli, O., 2008. Management of Natura 2000 habitats. 6210 Semi-atural dry grasslands and scrubland facies on calcareous substrates (Festuco-Brometalia) (*important orchid sites). Technical Report 2008 12/24. European Commission.

Caldwell, M.M., Richards, J.H., 1986. Competing root systems: morphology and models of absorption. In: Givnish, T.J. (Ed.), On the Economy of Plant Form and Function. Cambridge University Press, Cambridge, pp. 251-273.

Canadell, J., Zedler, P.H., 1994. Underground structures of woody plants in Mediterranean ecosystems of Australia, California, and Chile. In: Arroyo, M.T.K., Zedler, P.H., Fox, M.D. (Eds.), Ecology and Biogeography of Mediterranean Ecosystems in Chile, California, and Australia. Springer-Verlag, New York, pp. 177-210.

Castroviejo, S., 1986-2012. Flora iberica 1-8, 10-15, 17-18, 21. Real Jardín Botánico, CSIC, Madrid.

Catford, J.A., Daehlerb, C.C., Murphyc, H.T., Sheppardd, A.W., Hardestyc, B.D., Westcottc, D.A., Rejmáneke, M., Bellinghamf, P.J., Perglg, J., Horvitzh, C., Hulmei, E., 2012. The intermediate disturbance hypothesis and plant invasions: implications for species richness and management Perspec. Plant Ecol. 4 (3), 231-241.

CFA - Centro Flora Autoctona, 2007. Germinazione e conservazione di Orchidee autoctone delle Prealpi Lombarde. http://www.parcobarro.lombardia.it/_cfa/index.php? option $=$ com_content\&task $=$ view\&id $=40 \& I t e m i d=0$ (accessed September 2007).

Chytrý, M., Otýpková, Z., 2003. Plot sizes used for phytosociological sampling of European vegetation. J. Veg. Sci. 14, 563-570.

Claessens, L., Verburg, P.H., Schoorl, J.M., Veldkamp, A., 2006. Contribution of topographically based landslide hazard modelling to the analysis of the spatial distribution and ecology of kauri (Agathis australis). Landsc. Ecol. 21, 63-76.

Connell, J.H., 1978. Diversity in tropical rain forests and coral reefs. Science 199 (4335), 302-1310.

Core Team, R., 2015. R: A Language and Environment for Statistical Computing. Version 3.2.0. R Foundation for Statistical Computing, Vienna, Austriahttp://www.R-project. org

Costa, J.C., Neto, C., Aguiar, C., Capelo, J., Espírito-Santo, M.D., Honrado, J., Pinto-Gomes, C., Monteiro-Henriques, T., Sequeira, M., Lousa, M., 2012. Vascular plant communities in Portugal (continental, the Azores and Madeira). Global Geobotany 2 (1), 1-180.

The lowland grassland management handbook. In: Crofts, A., Jefferson, R.G. (Eds.), English Nature/The Wildlife Trusts, 2nd ed Royal Society for Nature Conservation.

Cruz, C.P., Espirito-Santo, M.D., 1999. Habitats naturais da Serra de Montejunto. Quercetea. 1 pp. 103-116.

Dalling, J.W., 1994. Vegetation colonization of landslides in the Blue Mountains, Jamaica. Biotropica 26, 392-399.

del Moral, R., Walker, L.R., 2007. Environmental Disasters, Natural Recovery and Human Response. Cambridge University Press, Cambridge.

Dengler, J., Löbel, S., Dolnik, C. 2009. Species constancy depends on plot size - a problem for vegetation classification and how it can be solved. J. Veg. Sci. 20 (4), 754-766.

EC - European Commission, 2007. Interpretation Manual of European Union Habitats EUR 27 July 2007.

Elias, R.B., Dias, E., 2004. Primary succession on lava domes on Terceira (Azores). J. Veg. Sci. $15,331-338$

Elias, R.B., Dias, E., 2009. Effects of landslides on the mountain vegetation of Flores Island. Azores. J. Veg. Sci. 20, 706-717.

Ferreira, A.B., Zêzere, J.L., 1997. Portugal and the Portuguese Atlantic Islands. In: Embleton, C., Embleton-Hamman, C. (Eds.), Geomorphological Hazards of Europe, Developments in Earth Surface Processes. Elsevier, Amsterdam, pp. 391-407.

Fetcher, N., Haines, B.L., Cordero, R.A., Lodge, D.J., Walker, L.R., Fernandez, D.S., Lawrence, W.T., 1996. Responses of tropical plants to nutrients and light on a landslide in Puerto Rico. J. Ecol. 84, 331-341.

Fitter, A.H., 1991. Characteristics and functions of root systems. In: Waisel, Y., Eshel, A., Kafkafi, U. (Eds.), Plant Roots. The Hidden Half. Marcel Dekker, Inc., New York, pp. 3-25.

Flaccus, E., 1959. Revegetation of landslides in the White Mountains of New Hampshsire. Ecology 40 (4), 692-703.

Fox, J.W., 2013. The intermediate disturbance hypothesis should be abandoned. Trends Ecol. Evol. 28 (2), 86-92.

Francescato, V., Scotton, M., 1999. Analisi di vegetazioni colonizzatrici di frane su flysch e morena calcarea del bellunese. L'Italia Forestale e Montana. 6, 324-349.

Francescato, V., Scotton, M., Zarin, D.J., Innes, J.C., Bryant, D.M.F., 2001. Fifty years of natural revegetation on a landslide in Franconia Notch, New Hampshire, U.S.A. Can. J. Bot. 79 (12), 1477-1485

Franco, A., 1971, 1984. Nova Flora de Portugal (Continente e Açores) Vol. I, II. Escolar Editora, Lisboa.

Franco, A., Rocha Afonso, M.L., 1994, 1998, 2003. Nova Flora de Portugal (Continente e Açores), Vol. III (Fascículos I, II, III). Escolar Editora, Lisboa.
Franklin, J.F., MacMahon, J.A., Swanson, F.J., Sedell, J.R., 1985. Ecosystem responses to the eruption of Mount St. Helens. Natl. Geogr. Res. 1, 198-216.

Geertsema, M., Pojar, J., 2007. Influence of landslides on biophysical diversity - a perspective from British Columbia. Geomorphology 89, 55-69.

Gers, E., Florin, N., Gartner, H., Glade, T., Dikau, R., Schweingruber, F.R., 2001. Application of shrubs for dendrogeomorphological analysis to reconstruct spatial and temporal landslide movement patterns. A preliminary study. Z. Geomorphol. 125, 163-175.

Guariguata, M.R., 1990. Landslide disturbance and forest regeneration in the upper Luquillo Mountains of Puerto Rico. J. Ecol. 78, 814-832.

Guerrero-Campo, J., Palacio, S., Pérez-Rontomé, C., Montserrat-Martí, G., 2006. Effect of root system morphology on root-sprouting and shoot-rooting abilities in 123 plant species from eroded lands in north-East Spain. Ann. Bot. 98 (2), 439-447.

Gupta, R., Mukerji, K.G., 2006. Arbuscular Mycorrhizal Associations in Agricultural Plants Including Weeds. In: Mukerji, K.G., Manoharchary, C. (Eds.), Concepts in Botany. New Delhi, I.K. International.

Hall, A.R., Miller, A.D., Leggett, H.C., Roxburgh, S.H., Buckling, A., Shea, K., 2012. Diversitydisturbance relationships: frequency and intensity interact. Biol. Lett. 8 (5), 768-771.

Highland, L.M., Bobrowsky, P., 2008. The landslide handbook-A guide to understanding landslides. Circular 1325. U.S. Geological Survey, Reston, Virginia.

JNCC, et al., 2007. JNCC and the UK Statutory Nature Conservation Agencies Lowland Grassland Lead Co-ordination Network 2007. Second Report by the United Kingdom Under Article 17 on the Implementation of the Directive From January 2001 to December 2006. Audit Trail Supporting Conservation Status Assessment for Habitat: H6210: Semi-natural Dry Grasslands and Scrubland Facies: On Calcareous Substrates (Festuco-Brometalia).

Kercher, S.M., Frieswyk, C.B., Zedler, J.B., 2009. Effects of sampling teams and estimation methods on the assessment of plant cover. J. Veg. Sci. 14 (6), 899-906.

Kraus, T.A., Bianco, C.A., Weberling, F., 2003. Root system morphology of Fabaceae species from central Argentina. Wulfenia 10,61-72.

Kricher, J.C., 2011. Tropical Ecology. Princeton University Press, New Jersey.

Kummerow, J., 1981. Structure of roots and root systems. In: Di Castri, F., DW, G., RL, S. (Eds.), Ecosystems of the World -11. Mediterranean-type Shrublands. Elsevier, Amsterdam, pp. 269-288.

LIFE Nature project LIFE2002/NAT/D/8461, d. Layman Report. Restoration and conservation of xeric grasslands in Germany (Rhineland-Palatine). Stiftung Natur und Umwelt Rheinald-Pfalz, Germany, 2002-2006http://ec.europa.eu/environment/life/project/ Projects/files/laymanReport/LIFE02_NAT_D_008461_LAYM AN.pdf.

Lundgren, L., 1978. Studies of soil and vegetation development on fresh landslide scars in the Mgeta Valley, Western Ulugura Mountains, Tanzania. Geogr. Ann. 60 (A), 91-127.

Mackey, R., Currie, D., 2001. The diversity-disturbance relationship: is it generally strong and peaked? Ecology 82 (12), 3479-3492.

Mark, A.E., Dickinson, K.J.M., Fife, A.J., 1989. Forest succession on landslides in the Fiord Ecological Region, southwestern New Zeal. J. Bot. 27, 369-390.

Mueller-Dombois, D., Ellenberg, H., 1974. Aims and Methods of Vegetation Ecology. John Wiey and Sons, New York.

Mueller-Dombois, D., Ellenberg, H., 2003. Aims and Methods of Vegetation Ecology. Reprint of 1st Edition. Blackburn Press 978-1930665736.

Myster, R., 1997. Seed predation, disease and germination on landslides in neotropical Lower Montane Wet Forest. J. Veg. Sci. 8 (1), 55-64.

Myster, R.W., Femández, D.S., 1995. Spatial gradients and patch structure on two Puerto Rican landslides. Biotropica 27, 149-159.

Myster, R.W., Sarmiento, E.O., 1998. Seed inputs to micro site patch recovery on two tropandean landslides in Ecuador. Restor. Ecol. 6, 35-43.

Myster, R.W., Walker, L.R., 1997. Plant successional pathways on Puerto Rican landslides, J. Trop. Ecol. 13, 165-173.

Novák, V., Simunek, J., van Genuchten, M.T., 2000. Infiltration of water into soil with cracks. J. Irrig. Drain. E.-ASCE 126 (1), 41-47.

Oliveira, S.C., Zêzere, J.L., Catalão, J., Nico, G., 2015. The contribution of PSInSAR interferometry to landslide hazard in weak rocks dominated areas. Landslides 12 (4), 703-719.

Otypková, Z., Chytry, M., 2006. Effects of plot size on the ordination of vegetation samples. J. Veg. Sci. $17,465-472$

Pearson, R., Gibson, A.D., Inkpen, R., 2013. Biodiversity and species succession of the black Ven - Spittle's landslide complex, Dorset. Geoscience in South-West England 13, 228-231.

Pihl, S., Ejrnæs, R., Søgaard, B., Aude, E., Nielsen, K.E., Dahl, K., Laursen, J.S., 2001. Habitats and Species Covered by the EEC Habitats Directive. A Preliminary Assessment of Distribution and Conservation Status in Denmark. National Environmental Research Institute, Denmark NERI Technical Report No. 365.

Raunkiær, C., 1934. The Life Forms of Plants and Statistical Plant Geography. Clarendon Press, Oxford.

Reddy, V.S., Singh, J.S., 1993. Changes in vegetation and soil during succession following landslide disturbance in the central Himalaya. J. Environ. Manag. 39, 235-250.

Restrepo, C., Alvarez, N., 2006. Landslides and their contribution to land-cover change in the mountains of Mexico and Central America. Biotropica 38, 446-457.

Restrepo, G., Vitousek, P.M., 2001. Landslides, alien species, and the diversity of a Hawaiian montane mesic ecosystem. Biotropica 33, 409-420.

Restrepo, C., Walker, L.R., Shiels, A.B., Bussmann, R.W., Claessens, L., Fisch, S., Lozano, P., Negi, G., Paolini, L., Poveda, G., Ramos-Scharrón, C., Richter, M., Velázquez, E., 2009. Landsliding and its multi-scale influence on mountainscapes. Bioscience 59 (8), 685-698.

Roberts, D.W., 2015. Labdsv: ordination and multivariate analysis for ecology. R package version 1, 7-0 (Available at:) http://CRAN.R-project.org/package=labdsv

Sakai, A., Ohsawa, M., 1993. Vegetation pattern and microtopography on a landslide scar of Mt. Kiyosumi, central Japan. Ecol. Res. 8, 47-56.

Schaetzl, R., Thompson, M.L., 2015. Soils. Genesis and Geomorphology. 2nd Ed. Cambridge University Press, New York. 
Shiels, A.B., Walker, L.R., 2003. Bird perches increase forest seeds on Puerto Rican landslides. Restor. Ecol. 11, 457-465.

Shiels, A.B., Walker, L.R., 2013. Landslides cause spatial and temporal gradients at multiple scales in the Luquillo Mountains of Puerto Rico. Ecol. Bull. 54, 211-222.

Shiels, A.B., West, C.A., Weiss, L., Klawinski, P.D., Walker, L.R., 2008. Soil factors predict initial plant colonization on Puerto Rican landslides. Plant Ecol. 195, 165-178.

Song, Y., Turkington, R., Zhou, D., 2012. Soil fissures help in the restoration of vegetation on secondary bare alkali-saline soil patches on the Sougnen plain. China. J. Soil Water Conserv. 67 (1), 24A-25A

Stokes, A., Lucas, A., Jouneau, L., 2007. Plant biomechanical strategies in response to frequent disturbance: uprooting of Phyllostachys nidularia (Poaceae) growing on landslide-prone slopes in Sichuan. China. Am. J. Bot. 94 (7), 1129-1136.

Ter Braak, C.J.F., Šmilauer, P., 2012. Canoco Reference Manual and User's Guide: Software for Ordination, Version 5.0. Microcomputer Power, Ithaca, USA.

Thomas, M.B., Spurway, M.I., 2001. Kowhai (sophora species) and other nitrogen-fixing plants of New Zealand. Combined Proceedings International Plant Propagators Society $51,94-97$.

Tyteca, D., 1998. The orchid flora of Portugal. J. Europaischer Orchiden 29 (2/3), 85-581.

van der Maarel, E., 2005. Vegetation ecology an overview. In: van der Maarel, E., Franklin, J. (Eds.), Vegetation Ecology, 2nd Ed West Sussex, Wiley-Blackwell, pp. 1-51.

Velázquez, E., Gómez-Sal, A., 2008. Landslide early succession in a neotropical dry forest. Plant Ecol. 199, 295-308.

Velázquez, E., Gómez-Sal, A., 2009. Changes in the herbaceous communities on the landslide of the Casita Volcano, Nicaragua, during early succession. Folia Geobot. 44, 1-18.

Velázquez, E., De la Cruz, M., Gómez-Sal, A., 2014. Changes in spatial point patterns of pioneer woody plants across a large tropical landslide. Acta Oecol. 61, 9-18.

Vesk, P.A., Westoby, M., 2004. Sprouting ability across diverse disturbances and vegetation types worldwide. J. Ecol. 92, 310-320.

Walker, L.R., 1993. Nitrogen fixers and species replacements in primary succession. In: Miles, D., Walton, W.H. (Eds.), Primary Succession on Land. Blackwell, Oxford, pp. 249-272.

Walker, L.R., Boneta, W., 1995. Plant and soil responses to fire on a fern-covered landslide in Puerto Rico. J. Trop. Ecol. 11, 473-479.

Walker, L.R., del Moral, R., 2003. Primary Succession and Ecosystem Rehabilitation. Cambridge University Press, Cambridge.

Walker, L.R., del Moral, R., 2009. Lessons from primary succession for restoration of severely damaged habitats. Appl. Veg. Sci. 12, 55-67.

Walker, L.R., Shiels, A., 2013. Landslide Ecology. Cambridge University Press, Cambridge.

Walker, L.R., Zarin, D.J., Fetcher, N., Myster, R.W., Johnson, A.H., 1996. Ecosystem development and plant succession on landslides in the Caribbean. Biotropica 28, 566-576.
Walker, L.R., Velazquez, E., Shiels, A.B., 2009. Applying lessons from ecological succession to the restoration of landslides. Plant Soil 324, 157-168.

Walker, L.R., Landau, F.H., Velazquez, E., Shiels, A.B., Sparrow, A., 2010a. Early successional woody plants facilitate and ferns inhibit forest development on Puerto Rican landslides. J. Ecol. 98, 625-635.

Walker, L.R., Wardle, D.A., Bardgett, R.D., Clarkson, B.D., 2010b. The use of chronosequences in studies of ecological succession and soil development. J. Ecol. 98, 725-736

Walker, L.R., Shiels, A.B., Bellingham, P.J., Sparrow, A.D., Fetcher, N., Landau, F.H., Lodge, D.J., 2013. Changes in abiotic influences on seed plants and ferns during 18 years of primary succession on Puerto Rican landslides. J. Ecol. 101, 650-661.

Westhoff, V., van der Maarel, E., 1978. The Braun-Blanquet Approach. In: Whittaker, R.H. (Ed.), Classification of Plant, 2nd Ed Junk, The Hague, pp. 287-297.

White, P.S., Jentsch, A., 2001. The search for generality in studies of disturbance and ecosystem dynamics. Prog. Bot. 63, 399-449.

Wilcke, W., Valladarez, H., Stoyan, R., Yasina, S., Valarezob, C., Zecha, W., 2003. Soil properties on a chronosequence of landslides in montane rain forest, Ecuador. Catena 53, 79-95.

Wilkinson, D.M., 1999. The disturbing history of intermediate disturbance. Oikos 84 (1), 145-147.

Zarin, D.J., Johnson, A.H., 1995a. Base saturation, nutrient cation, and organic matter increases during early pedogenesis on landslide scars in the Luquillo. Experimental Forest, Puerto Rico. Geoderma 65, 317-330.

Zarin, D.J., Johnson, A.H., 1995b. Nutrient accumulation during primary succession in a montane tropical forest. Puerto Rico. Soil Sci. Soc. Am. J. 59, 1444-1452.

Zêzere, J.L., Trigo, R.T., 2011. Impacts of the North Atlantic Oscillation on landslides. Vicente-Serrano SM, Trigo RM Eds. Hydrological, Socioeconomic and Ecological Impacts of the North Atlantic Oscillation in the Mediterranean Region. Advances in Global Change Research 46. Springer Science + Business Media BV, pp. 199-212.

Zêzere, J.L., Ferreira, A.B., Rodrigues, M.L., 1999. Landslides in the north of Lisbon region (Portugal): conditioning and triggering factors. Phys Chem Earth Pt. A 24, 925-934.

Zêzere, J.L., Trigo, R., Trigo, I., 2005. Shallow and deep landslides induced by rainfall in the Lisbon region (Portugal): assessment of relationships with the North Atlantic Oscillation. Nat. Hazard Earth Syst. 5, 331-344.

Zêzere, J.L., Trigo, R.T., Fragoso, M., Oliveira, S.C., Garcia, R., 2008. Rainfall-triggered landslides in the Lisbon region over 2006 and relationships with the North Atlantic Oscillation. Nat. Hazard Earth Syst. 8, 483-499.

Zêzere, J.L., Vaz, T., Pereira, S., Oliveira, S.C., Marques, R., Garcia, R., 2015. Rainfall thresholds for landslide activity in Portugal. Environ. Earth Sci. 73 (6), 2917-2936. 